\title{
Temperature and seston quantity and quality effects on field reproduction of farmed oysters, Crassostrea gigas, in Bourgneuf Bay, France
}

\author{
Mickaël Dutertre ${ }^{1, a}$, Peter G. Beninger ${ }^{1}$, Laurent Barillé ${ }^{1}$, Mathias Papin ${ }^{2}$, Philippe Rosa ${ }^{1}$, \\ Anne-Laure Barillé ${ }^{3}$ and Joël Haure ${ }^{2}$ \\ 1 Université de Nantes, Nantes Atlantique Universités, Équipe Mer-Molécules-Santé EA 2160, Faculté des Sciences et des Techniques, \\ 2 rue de la Houssinière, BP 92208, 44322 Nantes, France \\ 2 IFREMER, Laboratoire conchylicole des Pays de la Loire, Polder des Champs, 85230 Bouin, France \\ 3 BIO-LITTORAL, Faculté des Sciences et des Techniques, 2 rue de la Houssinière, BP 92208, 44322 Nantes, France
}

Received 9 March 2009; Accepted 28 July 2009

\begin{abstract}
The proliferation of the voluntarily-introduced cupped oyster, Crassostrea gigas, has attained the proportions of species invasion in many intertidal habitats in Europe, presumably resulting from successful reproduction of farmed individuals. It is thus imperative to better understand the reproductive characteristics of farmed oysters, since they are directly under human control. We quantified the dry tissue mass (DTM), gametosomatic index (GSI), and reproductive cycle of farmed oysters at two sites in Bourgneuf Bay, France, in relation to environmental parameters using continuously-recording probes in 2005 and 2006. The GSI was developed for this study, based on the actual area occupied by gametes, rather than the area of the gonad previously used for quantitative histological estimation of reproductive effort. The two sites, intermediate - (IT) and high-turbidity (HT), differed markedly in the amount and quality of particulate suspended matter, and also in fine-scale temperature variations. Oysters at both sites presented two spawning periods in both 2005 and 2006; Bourgneuf Bay is thus near the northernmost European limit for a 2spawning cycle in Crassostrea gigas. Gonad maturation was initiated when spring water temperature reached $8-10{ }^{\circ} \mathrm{C}$, and gamete atresia occurred when water temperatures transiently dipped to $15-18{ }^{\circ} \mathrm{C}$. Spawns, which occurred above $18^{\circ} \mathrm{C}$, were timed by fine-scale water temperature variations. Particulate organic matter quality peaks, coinciding with gonad maturation, were related to DTM variations before spawning periods, for the IT oysters in both years, and for the HT oysters in 2006. The reproductive effort (GSI) of oysters was similar at both sites; however, the fates of the gametes differed according to site. At the first spawning, the IT oyster gamete emissions were +1 month delayed, as were peak water temperatures greater than $18{ }^{\circ} \mathrm{C}$, and more pronounced, compared to the HT site. Although the second spawning showed high proportions of atretic oocytes at both sites in both years, the IT oysters evacuated twice as many gametes as the HT oysters in 2005. The IT conditions therefore appear more suited to Crassostrea gigas gamete evacuation than the HT conditions.
\end{abstract}

Key words: Reproduction / Temperature / Turbidity / Oocytes / Atresia / Biological invasion / Gametosomatic index / Bivalve / Oyster farming / Crassostrea gigas / Atlantic Ocean

Résumé - La prolifération de l'huître creuse volontairement introduite, Crassostrea gigas, a atteint les proportions d'une invasion biologique au niveau de nombreux habitats intertidaux en Europe, vraisemblablement en raison du succès de la reproduction des individus cultivés. Il est donc essentiel de mieux comprendre les caractéristiques de la reproduction des huîtres qui sont cultivées. Nous avons quantifié la masse de tissus secs (DTM), l'indice gaméto-somatique (GSI) et le cycle reproducteur des huîtres cultivées sur deux sites de la baie de Bourgneuf, en relation avec les paramètres environnementaux enregistrés en continu par des sondes, en 2005 et 2006. L'indice GSI, développé pour cette étude, est basé sur la surface réelle occupée par les gamètes, et non celle de la gonade utilisée antérieurement en histologie quantitative pour estimer l'effort de reproduction. Les deux sites, de turbidité intermédiaire (IT) et de forte turbidité (HT), diffèrent nettement dans la quantité et la qualité de la matière en suspension, et également dans la variabilité horaire de la température. Les huîtres présentent, dans les deux sites, deux périodes de pontes en 2005 et en 2006 ; la baie de Bourgneuf est donc proche de la limite nord du cycle à deux pontes chez Crassostrea gigas. La maturation des gonades

\footnotetext{
a Corresponding author: mickael.dutertre@univ-nantes.fr
} 
est initiée quand la température printanière de l'eau atteint $8-10^{\circ} \mathrm{C}$, et l'atrésie des gamètes se produit lorsque la température de l'eau descend transitoirement sous $15-18{ }^{\circ} \mathrm{C}$. Les pontes, induites au-dessus de $18{ }^{\circ} \mathrm{C}$, sont rythmées par la variabilité horaire de la température de l'eau. Des pics de qualité de la matière organique particulaire, coïncidant avec la maturation des gonades, sont liés aux variations de DTM avant les périodes de pontes pour les huîtres IT en 2005 et 2006, et pour les huîtres HT en 2006. L'effort de reproduction (GSI) des huîtres est similaire dans les deux sites ; cependant, le devenir des gamètes diffère suivant le site. Lors de la première ponte, les émissions de gamètes des huîtres IT sont décalées d'un mois, comme le sont les pics de température supérieurs à $18{ }^{\circ} \mathrm{C}$, et plus prononcées, comparées au site HT. Bien que la seconde ponte montre une grande proportion de gamètes atrésiques dans les sites en 2005 et 2006, les huîtres IT libèrent deux fois plus de gamètes que les huîtres HT en 2005. Les conditions IT semblent donc être plus favorables à l'émission des gamètes chez Crassostrea gigas que les conditions HT.

\section{Introduction}

Native populations of bivalve molluscs, which are one of the main components of estuarine and coastal ecosystems, have been exploited since at least the European Mesolithic (Dupont and Gruet 2005). In the twentieth century, bivalve species were introduced to European coasts for aquaculture purposes, such as the Japanese littleneck clam Tapes philippinarum or the robust, fast-growing Pacific cupped oyster Crassostrea gigas (Grizel and Héral 1991; Flassch and Leborgne 1992; Reise 1999; Gosling 2003; Ruesink et al. 2005). However, in the past decade, the expansion of the biogeographic distribution of $C$. gigas in Europe, unrelated to new introductions, as well as increasing population densities, suggests the proliferation of feral populations (i.e. wild populations originally derived from farmed populations - Grizel and Héral 1991; Drinkwaard 1999; Wehrmann et al. 2000; Diederich et al. 2005; Smaal et al. 2005; Cognie et al. 2006). Considering that oysters are important ecosystem engineers (see Ruesink et al. 2005 for review), increasing proliferation of feral oyster stocks could significantly impact coastal ecosystems around the world (Diederich 2006; Kochmann et al. 2008; Troost et al. 2009). A firm understanding of the reproductive biology of farmed $C$. gigas stocks is therefore particularly important (Brandt et al. 2008; Thresher et al. 2009), since not only are they assumed to be at the origin of the feral populations, but they are the only reproductive component directly under human control.

Gametogenesis, the central process of reproduction in bivalves, is predominantly influenced by both food availability (quality and quantity of suspended particulate matter - SPM) and water temperature (Andrews 1979; Sastry 1979; Mann 1979; Ruiz et al. 1992; Lango-Reynoso et al. 2000; ChávezVillalba et al. 2001, 2002, 2003; Fabioux et al. 2005). In C. gigas, reproductive events, such as gonad maturation and spawns, have been related to water temperature thresholds, themselves used to elaborate predictive growth models in order to manage field oyster populations (Barillé 1997; Kobayashi et al. 1997; van der Meer 2006). However, due to different laboratory conditioning, geographic locations and environmental monitoring accuracy, these thresholds vary over a wide range of temperature values (Mann 1979; Ventilla 1984; Dinamani 1987; Shpigel 1989; Fabioux et al. 2005; Cardoso et al. 2007). This range could conceivably be reduced using more precise and finer-scale temperature measurements.

Bivalve reproductive characteristics have not heretofore been investigated in relation to high turbidity conditions, which dominate in several of the habitat types, like estuaries and extensive intertidal mudflats of the French Atlantic coast and Wadden Sea, in which $C$. gigas currently proliferates (Cognie et al. 2006; Diederich 2006). The quantity and quality of the suspended particulate matter (SPM) greatly influence food quality and quantity available to C. gigas (Berg and Newell 1986; Fegley et al. 1992; Barillé et al. 1997; Beninger et al. 2008). In addition to enhanced temperature measurements, the use of continuously-recording environmental parameters could improve the understanding of the SPM dynamics, particularly in relation to $C$. gigas reproductive strategy in high-turbidity habitats.

Two broad approaches may be used in the field study of the bivalve reproductive cycle: monitoring dry tissue mass (gravimetric condition indices) and histological analysis of gonad activity (Thompson 1977; Sastry 1979; Robinson et al. 1981; DeVlaming et al. 1982; Beninger and Lucas 1984; Beninger 1987; Cardoso et al. 2007). Quantitative histological analysis conventionally estimates either the proportions of tissue types within the gonad (stereology), or the areas of gonad relative to the areas of somatic tissue (gonosomatic ratio, GSR). However, the latter technique does not differentiate between actual area occupied by gametes, and that occupied by the variable intra-acinal lumen and inter-acinal tissue. It is therefore necessary to devise an area-based technique that successfully discriminates gametic tissue only.

In order to elucidate the field reproductive biology of farmed Crassostrea gigas and the eventual influence of temperature and seston quantity and quality, we studied the reproductive characteristics of farmed oysters at two sites in Bourgneuf Bay, an important oyster-farming area characterized by a marked gradient of SPM concentration (Barillé et al. 2000), using continuously-recording environmental probes. A new index was developed to improve quantitative histology in which the "real" area occupied by gametes is compared to the total visceral mass.

\section{Materials and methods}

\subsection{Field sites and determination of environmental characteristics}

In 2005 and 2006, two oyster-farming sites in Bourgneuf Bay were selected for comparisons, based on marked turbidity differences (Barillé et al. 2000, Fig. 1). The northern high turbidity (HT) site, La Coupelasse $\left(47^{\circ} 1^{\prime} 34.7^{\prime \prime} \mathrm{N}, 2^{\circ} 1^{\prime} 55.9^{\prime \prime} \mathrm{W}\right)$, is a mudflat compared to the coarser sand-mud bottom of the southern intermediate turbidity (IT) site, Gresseloup (46 $57^{\prime}$ $\left.2.6^{\prime \prime} \mathrm{N}, 2^{\circ} 7^{\prime} 53.4^{\prime \prime} \mathrm{W}\right)$. At the HT site, more than $44 \%$ of the 


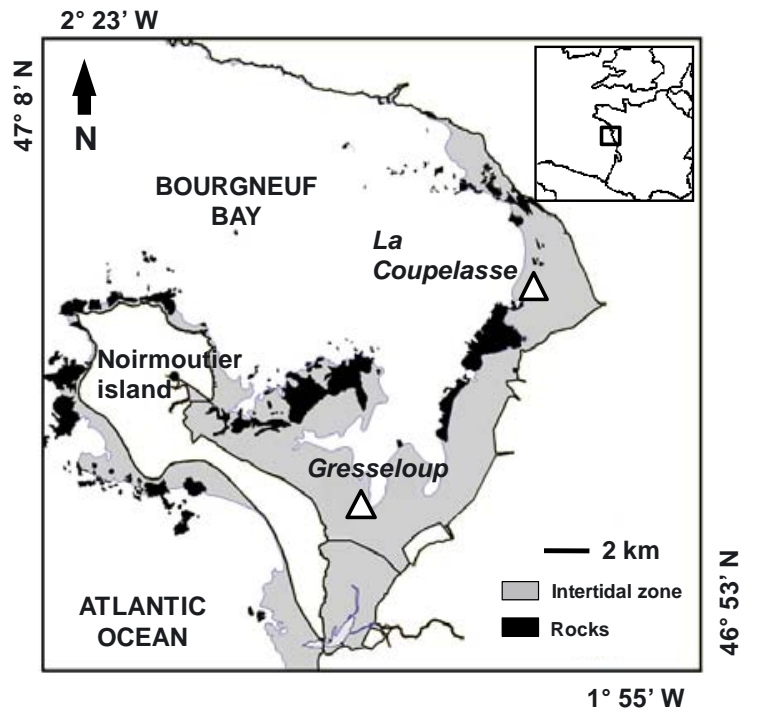

Fig. 1. Location of the northern high turbidity (HT, La Coupelasse) and southern intermediate turbidity (IT, Gresseloup) oyster sampling sites (4) in Bourgneuf Bay (modified from Barillé et al. 2000).

total weight of the sediment corresponds to a size fraction below $44 \mu \mathrm{m}$, vs. less than $10 \%$ at the IT site.

Multi-parameter water quality probes (YSI 6600) were fixed to oyster racks installed at each sampling site, to hourly record temperature $\left({ }^{\circ} \mathrm{C}\right)$, salinity (conductivity, psu), suspended particulate matter (SPM) concentration (nephelometry, NTU) and chlorophyll- $a$ concentration (fluorometry, \%). The corresponding monthly means were plotted with their $95 \%$ confidence intervals $(n=720)$.

Field calibrations were performed, both simultaneously from probe records, and from natural seawater samples collected at each oyster sampling site over two tidal cycles. Some seawater samples were dried at $60{ }^{\circ} \mathrm{C}$ for $48 \mathrm{~h}$ and then ashed at $450{ }^{\circ} \mathrm{C}$ for $4 \mathrm{~h}$ (Barillé-Boyer et al. 2003) to obtain SPM, particulate inorganic (PIM) and organic (POM) matter concentrations $\left(\mathrm{mg} \mathrm{L}^{-1}\right)$ respectively, while other samples were analysed by spectrophotometry after extraction with acetone (Lorenzen 1967) to determine chl- $a$ concentrations $\left(\mu \mathrm{g} \mathrm{L}^{-1}\right)$. Hourly probe records were then transformed into concentrations using the following regression equations:

$$
\begin{array}{r}
\mathrm{SPM}\left(\mathrm{mg} \mathrm{L}^{-1}\right)=1.44 \times \operatorname{turbidity}(\mathrm{NTU})+12.92, n=17 \\
r^{2}=0.93 \\
\mathrm{POM}\left(\mathrm{mg} \mathrm{L}^{-1}\right)=0.18 \times \operatorname{turbidity}(\mathrm{NTU})+3.42, n=17 \\
r^{2}=0.94 \\
\mathrm{Chl}-a\left(\mu \mathrm{g} \mathrm{L}^{-1}\right)=4.63 \times \operatorname{fluorometry}(\%)+1.65, n=16 \\
r^{2}=0.92
\end{array}
$$

Food availability and quality, herein defined as the percent of organic content of SPM (POM/SPM ratio) and the percent of chl- $a$ content of POM (chl- $a / \mathrm{POM}$ ratio), respectively, were calculated as follows:

$$
\begin{aligned}
\mathrm{POM} / \mathrm{SPM}(\%) & =\left(\mathrm{POM}\left(\mathrm{mg} \mathrm{L}^{-1}\right) / \mathrm{SPM}\left(\mathrm{mg} \mathrm{L}^{-1}\right)\right) \times 100 \\
\mathrm{Chl}-a / \operatorname{POM}(\%) & =\left(\operatorname{chl}-a\left(\mathrm{mg} \mathrm{L}^{-1}\right) / \operatorname{POM}\left(\mathrm{mg} \mathrm{L}^{-1}\right)\right) \times 100
\end{aligned}
$$

PIM was calculated as SPM - POM.

\subsection{Oyster sampling, biometric measurements and tissue fixation}

At the beginning of the study, in February 2005, adult farmed oysters (18 - month hatchery-born spat, origin Vendée Naissain, shell length $=69.2 \pm 4.9 \mathrm{SD} \mathrm{mm}$ ) were installed, at both the northern and southern sites, in $1.0 \times 0.5 \mathrm{~m}$ plastic, $20 \mathrm{~mm}$ mesh bags and tied to oyster racks $(3.0 \times 1.0 \mathrm{~m})$ at $0.6 \mathrm{~m}$ above the bottom. Each bag contained 280 individuals, corresponding to 5-10 kg of oysters. At each site, 45 farmed oysters were then sampled once monthly until March 2006 and then twice monthly until July 2006. The oysters, kept dry to avoid artificial spawns, were immediately transferred to the laboratory after collection and manually cleaned of their epibionts.

For each oyster, shell dimensions were measured with a caliper. Soft tissues of 30 oysters were then immediately recovered in pre-weighed aluminium cups and dried at $60{ }^{\circ} \mathrm{C}$ for $48 \mathrm{~h}$ to obtain dry tissue mass (DTM), while soft tissues of the other 15 oysters were fixed in cold Bouin's solution for histological purposes (Martoja and Martoja-Pierson 1967).

\subsection{Histological preparation}

After fixation, a $0.5 \mathrm{~mm}$-thick slice of the visceral mass was removed from the region along the line connecting the left and right palp-gill junctions (Morales-Alamo and Mann 1989). The tissue was rinsed under running water overnight, dehydrated and embedded in paraffin. Ten $7 \mu \mathrm{m}$ sections were performed per individual, and the sections were rehydrated, stained with a modified Masson's trichrome and dehydrated before being mounted on glass slides in mounting medium (Beninger et al. 2001). Mounted sections were then dried at $60{ }^{\circ} \mathrm{C}$ for at least one week.

\subsection{Gametosomatic index (GSI)}

In the present study we determined a gametosomatic index (GSI), which compared area of gametes to area of the total visceral mass on histological sections. The sections were digitized (Sony Cyber-Shot 7.2 MegaPixels) and stored for image analysis. LUCIA 4.80 software (Image Analysis Systems) was used to measure the whole visceral mass area (VMA), excluding gills and palps, as well as the area filled by gametes (gamete area, GA), in the 10 histological sections for each oyster. GSI, corresponding to the proportion of gamete area on the histological sections, was then calculated as:

$$
\operatorname{GSI}(\%)=\left(\operatorname{GA}\left(\mu \mathrm{m}^{2}\right) / \operatorname{VMA}\left(\mu \mathrm{m}^{2}\right)\right) \times 100 .
$$

Individual GSI means were averaged for each sampling date and each site.

\subsection{Gonadal tissue variations during the reproductive cycles}

Histological sections were observed $(200 \times)$ on a computer screen through a video camera mounted on an optical microscope (Olympus AX70). A $10 \times 10$ point matrix was used to 

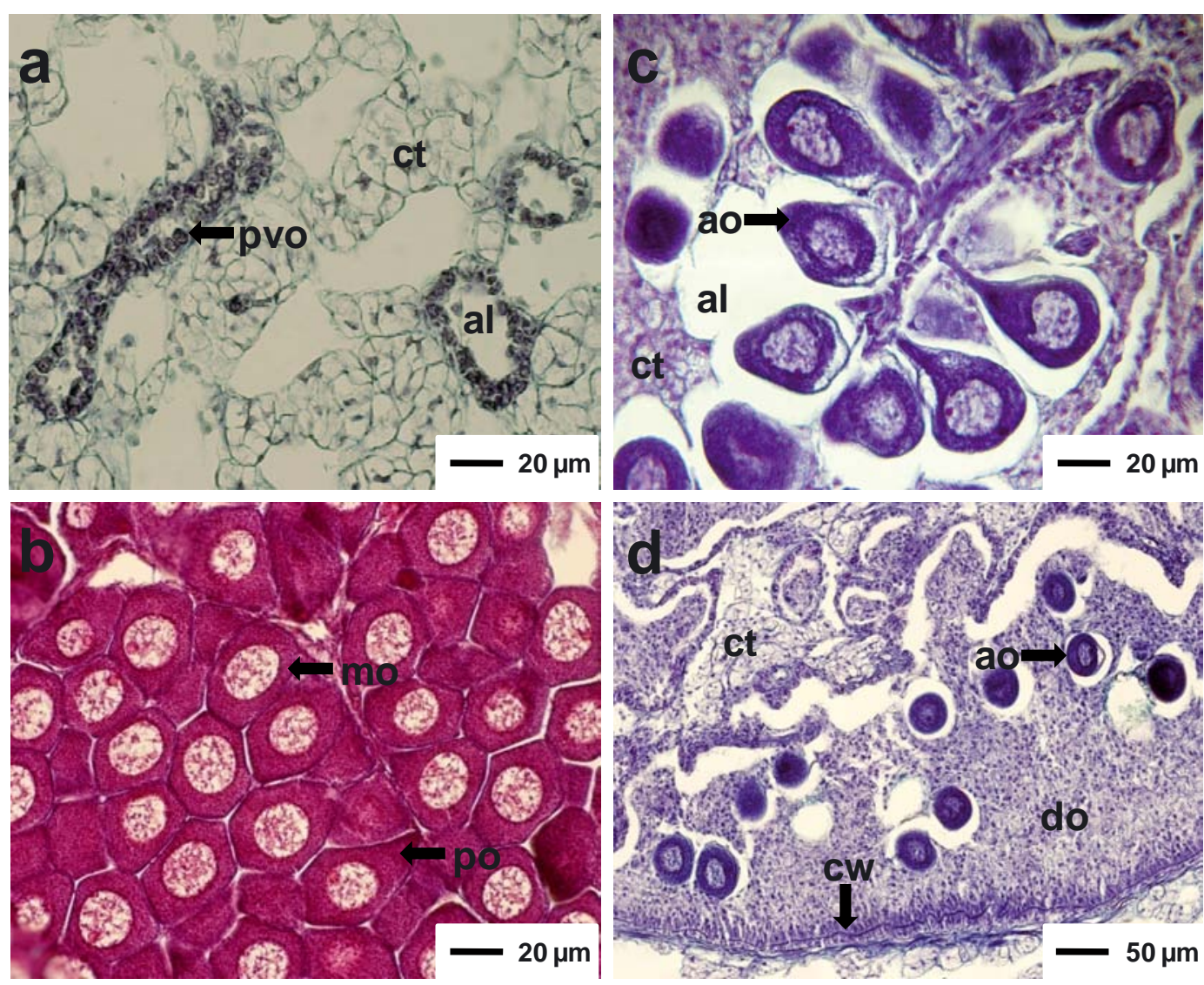

Fig. 2. Photomicrographs of oocytes in gonads of Crassostrea gigas. A: Pre-vitellogenic oocytes; B: Mature oocytes; C: Atretic oocytes in acinal lumen; D: Atretic oocytes in evacuating ducts. al: acinal lumen, ao: atretic oocyte, ct: connective tissue, cw: ciliated wall of evacuating duct, do: degenerated oocytes, mo: mature oocyte, po: pedunculated oocyte; pvo, pre-vitellogenic oocyte.

quantify the proportions of different types of tissue with stereological counts, which reflect variations in the different stages of the reproductive cycle (Beninger 1987; Morvan and Ansell 1988; Pazos et al. 1996; Beninger et al. 2001). Five gonadal tissue categories were identified for stereological purposes: interacinal connective tissue, developing gametes, mature gametes, acinal lumen and degenerating gametes (Fig. 2). As the loose nature of female gonad tissue can lead to artefacts in the proportion of acinal lumen, stereological counts were performed in three different gonadal regions in three histological sections per individual, excluding the regions of evacuating ducts. Significant variations in tissue proportions can therefore be attributed to natural mechanisms, while spawns are revealed by increases of the proportions of acinal lumen, as well as by the observations of free mature gametes in the evacuating ducts of the gonads. The percentage of each tissue was determined in relation to total gonadal tissue and individual means were subsequently averaged for each sampling date and each site.

\subsection{Statistical analysis}

Sigmastat 3.1 (Systat software) was used to check the normality and heteroscedasticity of data distributions, and subsequent statistical analyses. Annual means and seasonal variations of environmental factors were compared between sites by
Student $t$-tests and two-way ANOVA, respectively. Analyses of data from biometric measurements (DTM) and histological determinations (GSI and stereological counts) were performed using two-way parametric ANOVA. Student-Newman-Keuls (SNK) tests were used, where justified, in a posteriori analyses. Relationships between environmental factors within each site, as well as correlations between reproductive data, were determined with Spearman correlation tests (Conover 1999).

\section{Results}

\subsection{Environmental characteristics}

\section{Water temperature and salinity}

Water temperature variations at the two sites corresponded to the general pattern of a northern temperate nearshore ecosystem. The annual mean water temperature was equivalent at both oyster-farming sites, $13.8-13.9^{\circ} \mathrm{C}$, in 2005 and 2006 (Table $1, t$-test, $p=0.95$ and $p=0.99$, respectively). Fine - scale variations of water temperature, revealed by the calculations of the daily amplitudes, showed significant differences related to both site and year (Table 2, two-way ANOVA, $p<0.01)$. Daily water temperature amplitude was significantly higher at the HT site in both years (SNK-test, $p<0.01$ ), and in 2005 for both sites (SNK-test, $p<0.01$ ). 
Table 1. Annual means ( \pm standard deviations) of environmental factors at the northern high turbidity (HT) and southern intermediate turbidity (IT) sites in Bourgneuf Bay, in 2005 and 2006. Chl- $a$ : chlorophyll- $a$, PIM: particulate inorganic matter, POM: particulate organic matter, water temperature; $t$-tests were performed to compare annual mean values of environmental factors between sites.

\begin{tabular}{llccccc}
\hline & Turbidity $\left(\mathrm{mg} \mathrm{L}^{-1}\right)$ & $\begin{array}{c}\text { PIM } \\
\left(\mathrm{mg} \mathrm{L}^{-1}\right)\end{array}$ & $\begin{array}{c}\text { POM } \\
\left(\mu \mathrm{g} \mathrm{L}^{-1}\right)\end{array}$ & $\begin{array}{c}\text { Chl- } a \\
\text { temperature }\left({ }^{\circ} \mathrm{C}\right)\end{array}$ & $\begin{array}{c}\text { Water } \\
(\mathrm{psu})\end{array}$ \\
\hline \multirow{2}{*}{2005} & HT & $107.2 \pm 29.4$ & $16.9 \pm 4.1$ & $7.8 \pm 1.5$ & $13.8 \pm 6.0$ & $33.3 \pm 0.7$ \\
& IT & $21.7 \pm 15.8$ & $5.1 \pm 2.2$ & $1.8 \pm 0.9$ & $13.9 \pm 5.6$ & $33.3 \pm 1.6$ \\
& $p$ value & $<0.01$ & $<0.01$ & $<0.01$ & 0.95 & 0.93 \\
\hline 2006 & HT & $86.2 \pm 24.3$ & $17.6 \pm 11.7$ & $9.0 \pm 2.3$ & $13.9 \pm 6.0$ & $32.6 \pm 1.3$ \\
& IT & $25.6 \pm 13.0$ & $6.3 \pm 2.6$ & $3.6 \pm 1.3$ & $13.8 \pm 5.6$ & $31.9 \pm 2.2$ \\
& $p$ value & $<0.01$ & $<0.01$ & $<0.01$ & 0.99 & 0.10 \\
\hline
\end{tabular}

Table 2. Annual means ( \pm standard deviations) of daily water temperature amplitude at the northern high turbidity (HT) and southern intermediate turbidity (IT) sites in Bourgneuf Bay, in 2005 and 2006.

\begin{tabular}{cccc}
\hline & Turbidity & $\begin{array}{c}n \\
\text { (days) }\end{array}$ & $\begin{array}{c}\text { Daily water } \\
\text { temperature } \\
\text { amplitude }\left({ }^{\circ} \mathrm{C}\right)\end{array}$ \\
\hline 2005 & HT & 278 & $3.43 \pm 2.01$ \\
& IT & 251 & $2.39 \pm 1.63$ \\
& HT & 349 & $2.23 \pm 1.40$ \\
& IT & 347 & $1.78 \pm 1.29$ \\
\hline
\end{tabular}

The annual mean water salinity was also equivalent at the HT and IT sites in 2005 and 2006 (Table 1, $t$-test, $p=0.93$ and $p=0.10$, respectively). Salinity over the sampling period varied from 29.0 to $35.3 \mathrm{psu}$.

\section{Seston quantity and quality}

Over the sampling period, PIM, POM and chl- $a$ concentrations were always higher at the HT site compared to the IT site (Fig. 3, two-way ANOVA, $p<0.01$ ). The annual mean PIM concentrations at the HT site were nearly five times higher in 2005 and three times higher in 2006, compared to the IT site (Table $1, t$-test, $p<0.01$ ). The chl- $a$ concentration showed a positive correlation with SPM concentration at the HT site (Spearman test, $r=0.62, p<0.05$ ), with no discernable seasonal pattern. However, at the IT site, chl- $a$ concentration was negatively correlated with water temperature (Spearman test, $r=-0.79, p<0.01$ ), corresponding to spring and autumnal increases in chl- $a$ concentration when the water temperature was relatively low.

The POM/SPM ratio was higher at the IT site in 2005 and 2006 (Fig. 4a, two-way ANOVA, $p<0.01$ ). The chl- $a /$ POM ratio was higher at the HT site in 2005 , while no significant difference was reported in 2006 (Fig. 4b, two-way ANOVA, $p<0.01$ and $p=0.81$, respectively).

\subsection{Dry tissue mass (DTM) and gametosomatic index (GSI)}

In 2005 and 2006, oyster DTM and GSI showed significant differences between sites (Fig. 5 and Table 3). From March to July 2005, oysters from the IT site showed significant higher monthly DTM than those from the HT site
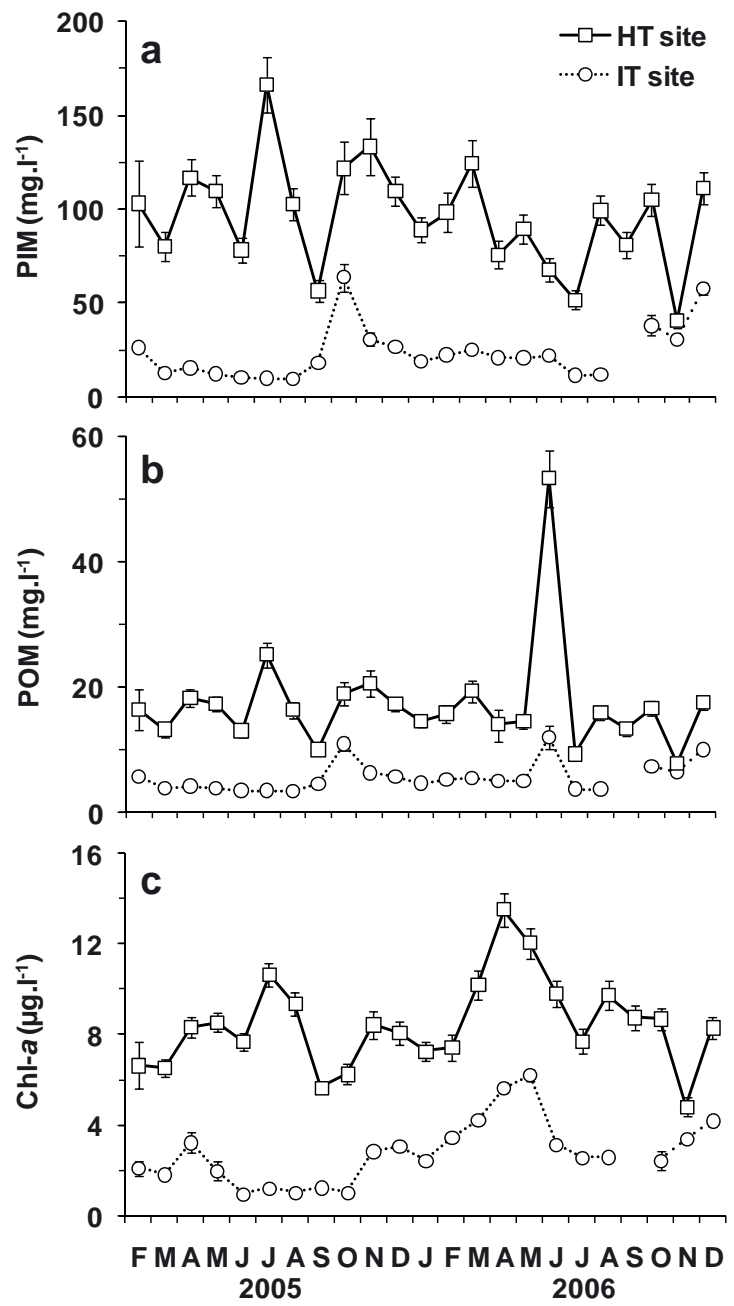

Fig. 3. Variations of particulate inorganic matter (PIM, a), particulate organic matter (POM, b) and chlorophyll- $a$ (chl- $a, \mathrm{c})$ concentrations (monthly means $\pm 95 \% \mathrm{CI}$ ) at northern high turbidity (HT) and southern intermediate turbidity (IT) sites of Bourgneuf Bay, in 2005 and 2006. Data for September 2006 are not reported for IT site, due to technical problems with the monitoring probe.

(SNK-tests, $p<0.05)$. Same differences between sites were observed from April to August 2006 (SNK-tests, $p<0.05$ ). On the other hand, comparing IT and HT sites, monthly oyster DTM were not statistically different between August 2005 and March 2006 (SNK-tests, $p>0.05$ ). As revealed by the 
Table 3. Two-way ANOVA analyses for Crassostrea gigas reproduction.

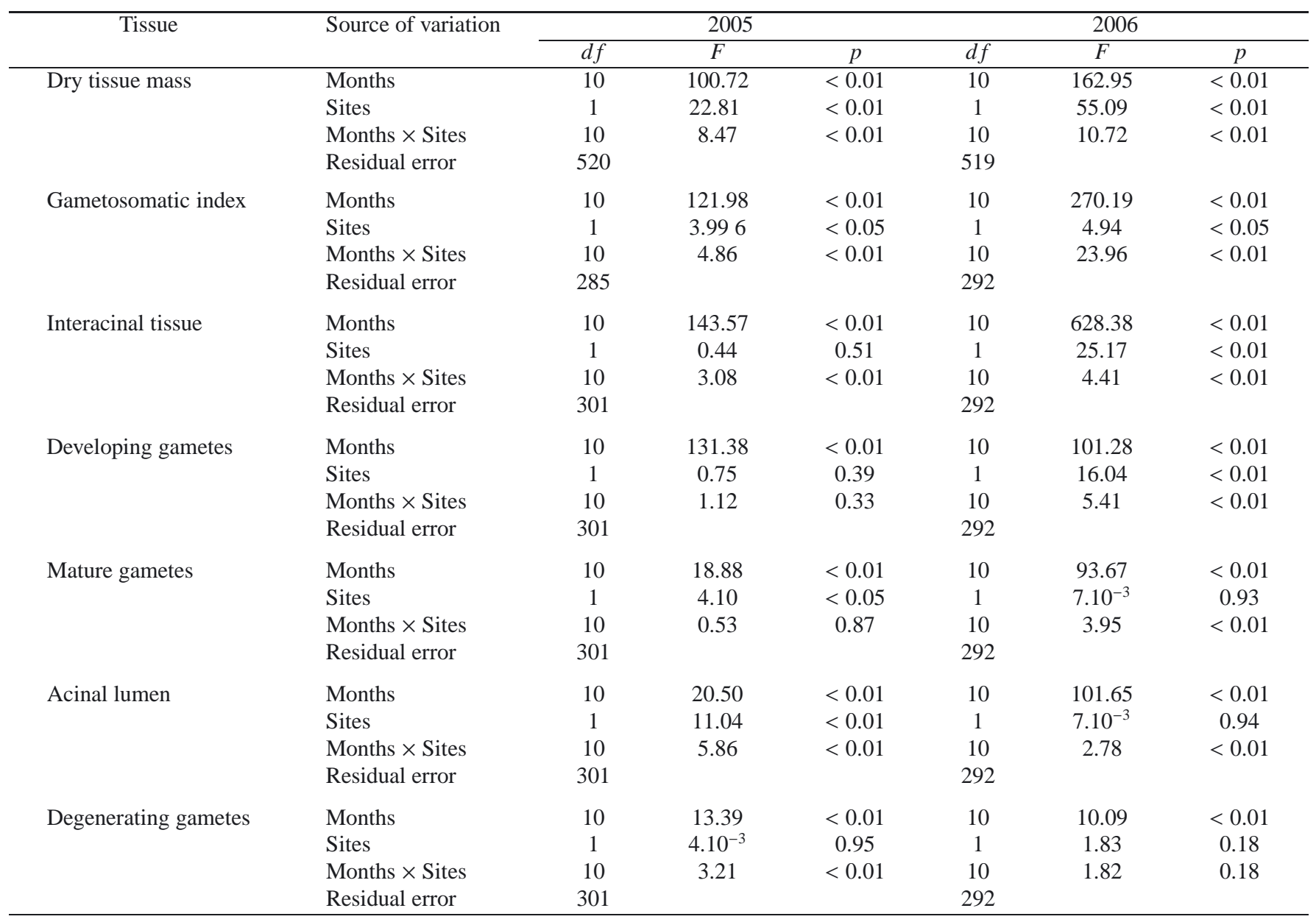

GSI (Fig. 5b), fine-scale variations of DTM were related to the reproductive cycles of the oysters.

\subsection{Reproductive cycle and gamete fates}

Over the sampling period, variations of the proportions of interacinal connective tissue and developing gametes were negatively correlated (Figs. 6a,b, Spearman correlation test, $r=-0.44, p<0.01)$. In 2005, variations of the proportions of interacinal connective tissue and developing gametes were not related to sites, while, in 2006, production of developing gametes, derived from interacinal tissue reserves, was faster at the HT site (Table 3). Proportions of mature gametes were significantly higher at the HT site compared to the IT site in 2005, while no significant difference was reported between sites in 2006 (Table 3 and Fig. 6c).

The evolution of the proportions of acinal lumen show the precise incidences of acinal filling (gamete production and maturation), and emptying (spawning), whereas the curves of degenerating gametes show the timing and extent of gamete resorption, either though atresia or resorption of residual gametes after spawning (Fig. 7). Together, these indices allow us to interpret the detailed fates of gametes produced. Two major spawning periods (late spring and late summer) were evident in both years. The first spawning period corresponded to a "normal" spawn, with negligible gamete degeneration in the acini. The second spawning period corresponded to an "atretic" spawn, in which a substantial proportion of degenerating gametes were observed in the acini. In both years, normal spawns were one-month delayed and more intense at the IT site than at the HT site (greater \% acinal lumen and lower GSI, SNK-tests, $p<0.01)$. In spite of the high proportion of degenerating oocytes at both sites at the atretic spawning periods, oysters from the IT site spawned more intensely than those at the HT site (greater \% acinal lumen, SNK-test, $p<0.01$, for non-significantly different GSI, SNK-test, $p=0.16$ ).

Examination of the hourly temperature values at each site allows us to relate gametogenic events, including atresia, to observed threshold temperatures (Fig. 8). Onset of gamete maturation begins at temperatures above $8-10{ }^{\circ} \mathrm{C}$, and spawning begins at temperatures above $18{ }^{\circ} \mathrm{C}$. The 1 -month spawning delay in the IT -site oysters corresponds to a 1-month delay in peak water temperatures greater than $18{ }^{\circ} \mathrm{C}$ at this site.

\section{Discussion}

\subsection{Gametogenesis and SPM quality}

Prior to spawning, both DTM and POM/SPM were significantly and clearly higher at the IT site compared to the HT site, 

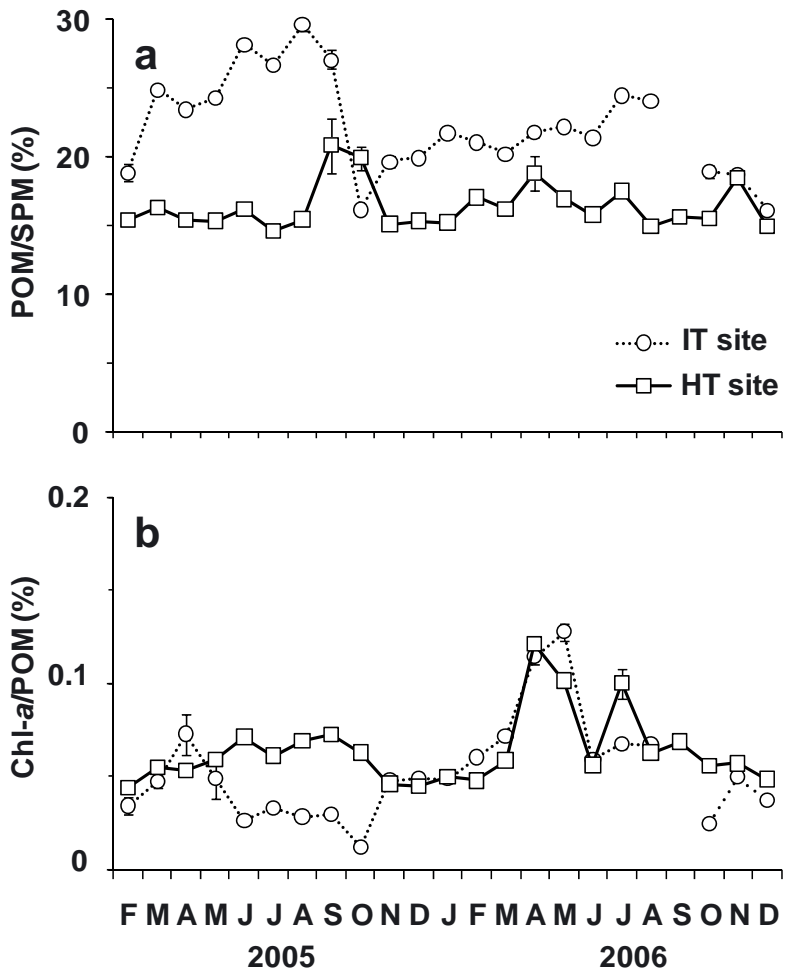

Fig. 4. Availability (POM/SPM, monthly means $\pm 95 \%$ CI, a) and quality (chl- $a / \mathrm{POM}$, monthly means $\pm 95 \% \mathrm{CI}, \mathrm{b}$ ) of organic particles at northern high turbidity (HT) and southern intermediate turbidity (IT) sites of Bourgneuf Bay, in 2005 and 2006. Chl- $a$ : chlorophyll- $a$, POM: particulate organic matter, SPM: suspended particulate matter. Data for September 2006 are not reported for IT site, due to technical problems with the monitoring probe.

while, except local peaks, water temperature was equivalent at both sites. This indicates that DTM differences result from site-specific SPM characteristics rather than temperature. At the IT site, the POM quality (chl-a/POM) shows spring peaks immediately preceding both spawnings, and coinciding with peaks in DTM. At the HT site, a peak in food quality is not evident in 2005, but is clearly evident in 2006, where once again it corresponds to a peak in DTM. Together with the developing gametes data, these field observations indicate that the increase in POM quality favourably affected gametogenesis, confirming previous laboratory demonstration (Chávez-Villalba et al. 2003). The increase in POM quality can be presumably related to phytoplankton abundance, which in turn may be quantitatively linked to reproduction (Bourlès et al. 2009). The intermediate-turbidity site showed greater POM quality peaks, and a corresponding greater oyster DTM peaks, than the highturbidity site in both 2005 and 2006. These data, as well as the greater POM availability at the IT site, thus suggest that the IT site SPM quality conditions are more favourable to organic matter assimilation.

\subsection{Reproductive cycle}

As demonstrated for other Atlantic French coastal areas, $C$. gigas reared in Bourgneuf Bay showed a seasonal reproductive
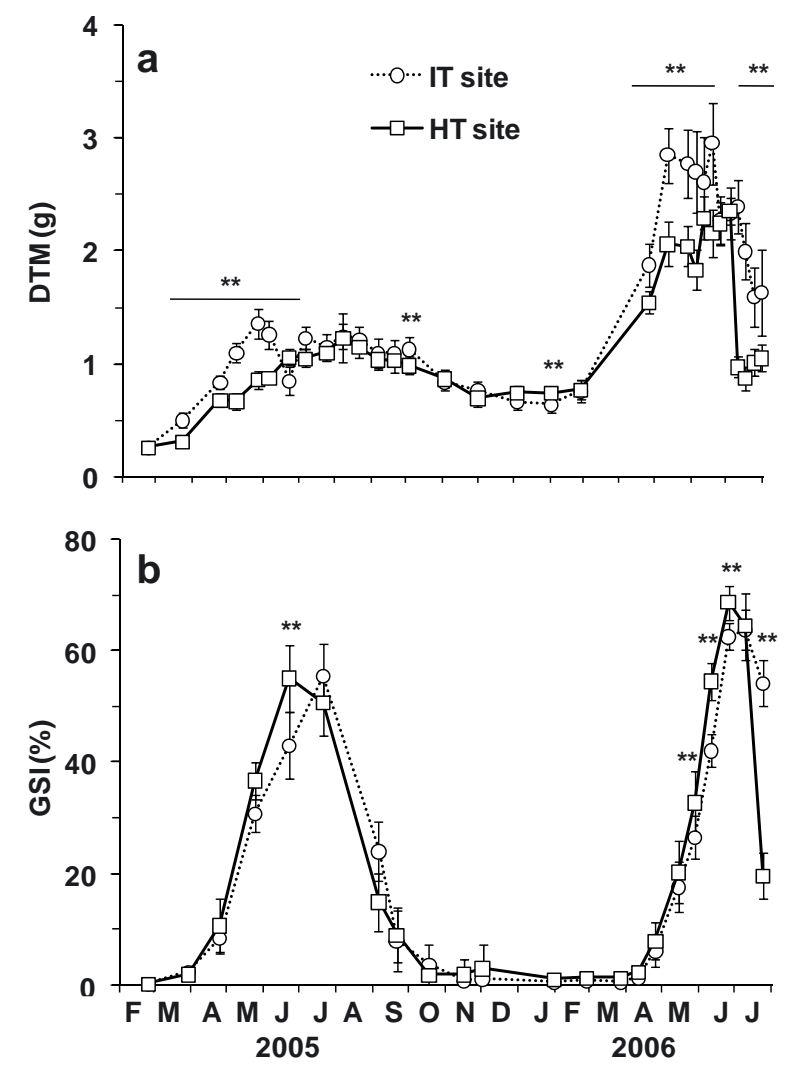

Fig. 5. Crassostrea gigas reared at the high (HT) and intermediate turbidity (IT) sites in Bourgneuf Bay, in 2005 and 2006. (a) Dry tissue mass (DTM, monthly means $\pm 95 \% \mathrm{CI}$ ), and (b) gametosomatic index (GSI, monthly means $\pm 95 \% \mathrm{CI}, * *=p<0.01$ ).

cycle closely related to water temperature (Lango-Reynoso et al. 2000; Chávez-Villalba et al. 2001). In 2005 and 2006, although gamete maturation began simultaneously at both sites, first spawns occurred one month later at the IT site compared to the HT site. Considering the geographical proximity of the study sites, this highlights the great spatial variability of the environmentally-dependant $C$. gigas reproductive strategy.

The two spawning periods observed in the present study are interesting from the standpoint of the geographical range of reproducing $C$. gigas and its' recent extension. The more southern Marennes-Oléron farming site also shows two spawning periods, whereas the more northern Veys Bay site shows only one (Enríquez-Díaz et al. 2009). The two Bourgneuf Bay sites appear to be near the northernmost limit of the two-spawning pattern, since of the two spawnings, one is characterized by a high proportion of atretic gametes.

The data of the present study clearly show that oysters grown under intermediate-turbidity conditions furnish a greater reproductive contribution at the first (normal) spawning than those grown under high-turbidity conditions. The turbidity at the HT site is exceptionally high for Atlantic European coastal ecosystems: to our knowledge, only the Wadden sea presents similar values, and then only during severe storms (Pejrup 1986; Barillé et al. 1997, 2000; Anderson and Pejrup 2001). The turbidities of the IT site are much more representative of most Atlantic European coastal ecosystems, which 

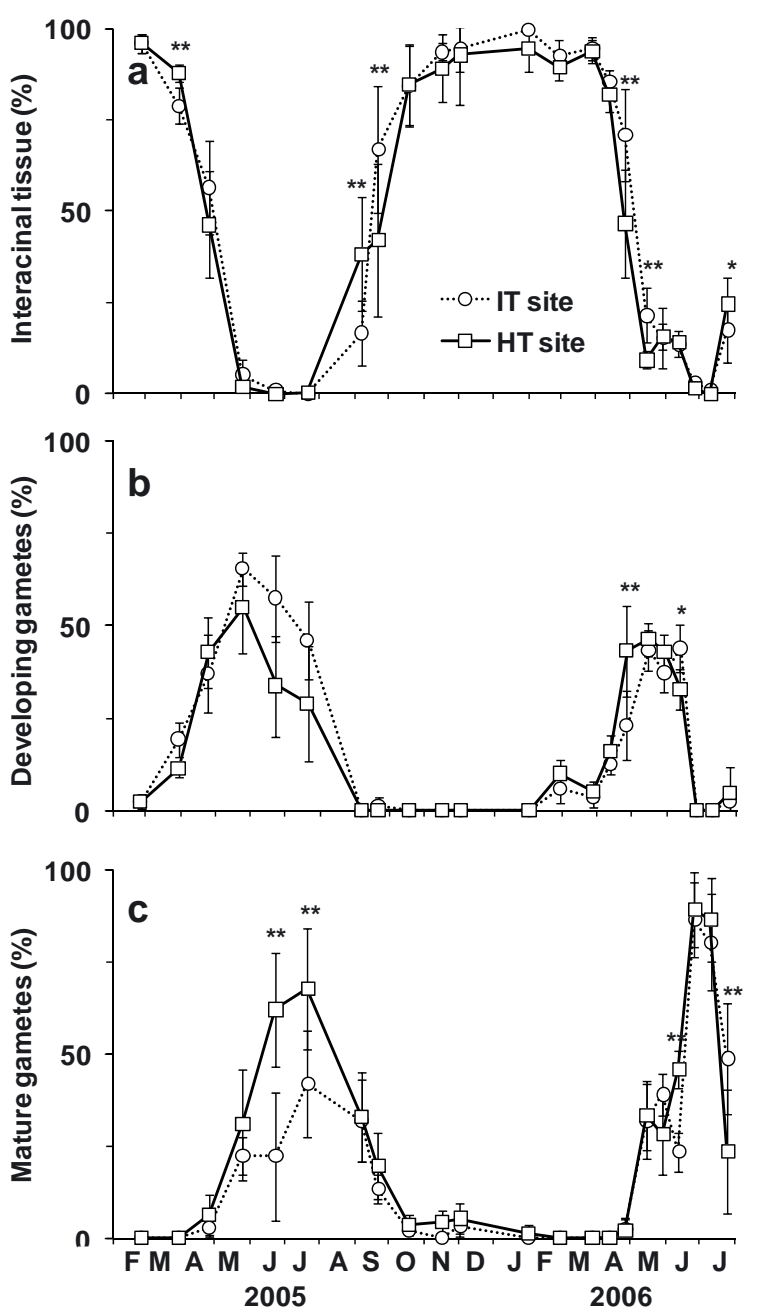

Fig. 6. Crassostrea gigas, reared at the high (HT) and intermediate turbidity (IT) sites in Bourgneuf Bay, in 2005 and 2006. Proportions (monthly means $\pm 95 \% \mathrm{CI}, * *=p<0.01, *=p<0.05$ ) of interacinal connective tissue (a), developing gametes (b) and mature gametes (c) compared to total gonadal tissue types.

thus present the most favourable turbidity conditions for the reproduction of $C$. gigas, both in farming operations and in the wild. Favourable turbidity conditions may therefore be a factor in the proliferation of feral oysters, now considered an invasive species (Drinkwaard 1999; Wehrmann et al. 2000; Diederich et al. 2005; Ruesink et al. 2005; Smaal et al. 2005; Cognie et al. 2006).

\subsection{Atresia}

Despite the importance of correctly evaluating the extent and prevalence of gamete atresia in bivalve reproductive cycles, only a few studies have done so in the Pectinidae (Lucas 1982; Lubet et al. 1987; Barber et al. 1988; Morvan and Ansell 1988; Dorange and Le Pennec 1989) and Mytilidae (Pipe 1987), and apart from mentioning the existence of "degenerating oocytes" (Steele and Mulcahy 1999; Lango-Reynoso et al. 2000), the phenomenon has not been studied at all in oysters.
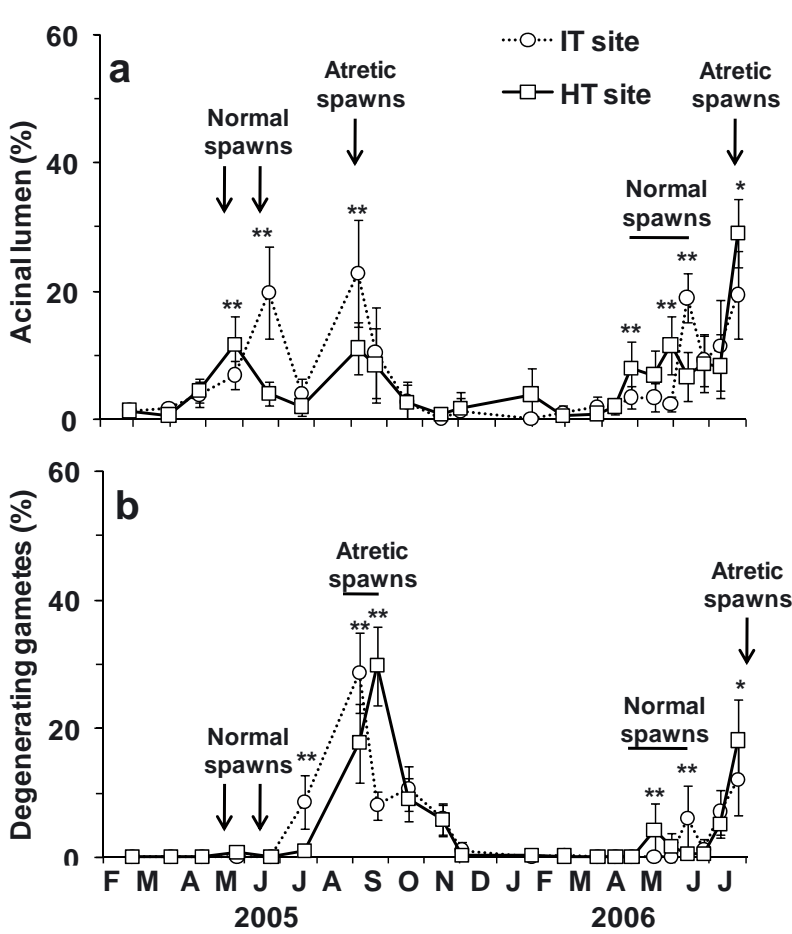

Fig. 7. Crassostrea gigas, reared at the high (HT) and intermediate turbidity (IT) sites in Bourgneuf Bay, in 2005 and 2006. Proportions (monthly means $\pm 95 \% \mathrm{CI}, * *=p<0.01, *=p<0.05$ ) of acinal lumen (a) and degenerating gametes (b) compared to total gonadal tissue types.

Although atretic gametes may be extruded, recycling within the individual should allow partial recovery of the invested energy (Le Pennec et al. 1991). It is thus interesting to note that the proportion of inter-acinal connective tissue rises concomittantly with the proportion of degenerating oocytes, suggesting reverse transfer of scavenged metabolites. A relationship has been hypothesized between the intensity of $C$. gigas oocyte atresia and trophic resource abundance (Chávez-Villalba et al. 2001). However, in the present work, both similar proportions of degenerating gametes and the onemonth delay of this process between sites characterized by marked differences in organic matter concentration suggest that oocyte atresia can be related to temperature conditions.

The limited data available indicate that the most favourable temperature for the development of $C$. gigas larvae is $22^{\circ} \mathrm{C}$ under field conditions (Seno et al. 1926; Arakawa 1990; Shatkin et al. 1997), and oyster hatcheries in Europe commonly rear larvae at temperatures $>19{ }^{\circ} \mathrm{C}$ (Chávez-Villalba et al. 2002; Rico-Villa et al. 2009). This coincides with major acinal emptying above $22{ }^{\circ} \mathrm{C}$. Maximal gamete atresia appears in mature C. gigas gonads when water temperatures transiently dip to $15-18{ }^{\circ} \mathrm{C}$, accelerating with the frequency of such dips. Such a situation occurs at the second, atretic spawning in both turbidity conditions in both 2005 and 2006. The present data thus suggest that the high rate of atresia at the second spawning may be related to unfavorable temperature conditions for subsequent larval development (Paulet et al. 1988). Although experimental studies of atresia induction would require significant 

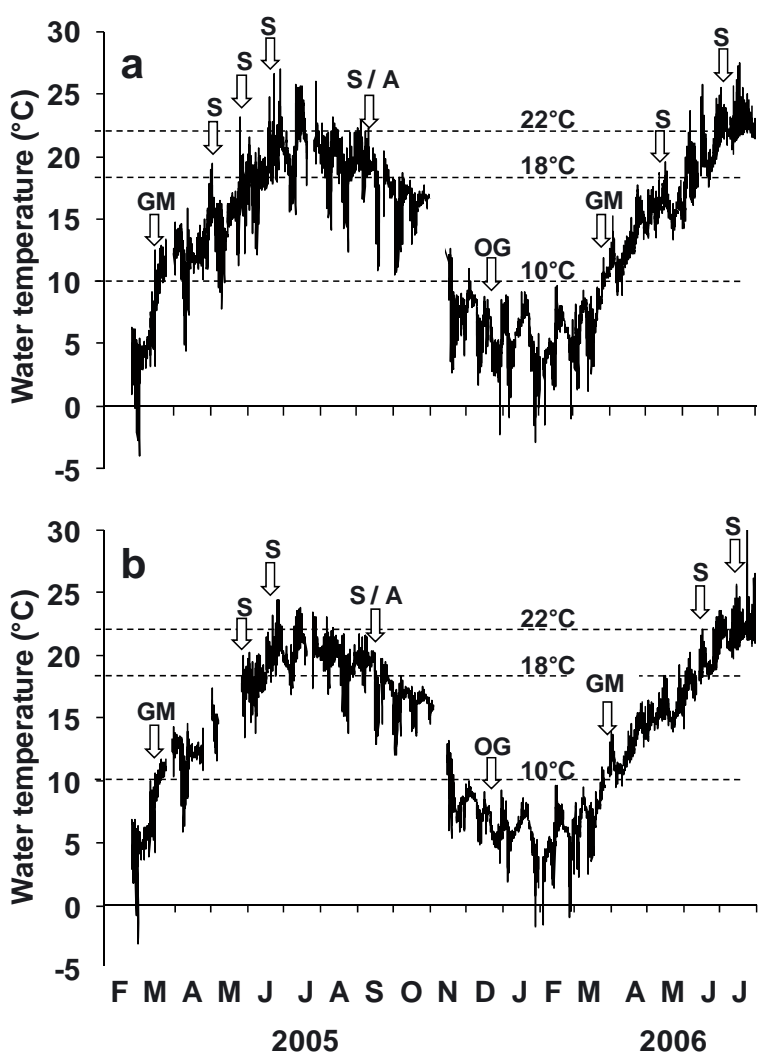

Fig. 8. Hourly variations of water temperature at the high turbidity (HT $-\mathrm{a})$ and intermediate turbidity (IT $-\mathrm{b})$ sites of Bourgneuf Bay, in 2005 and 2006. Arrows indicate oyster reproductive events; dotted lines represent main observed physiological thresholds of water temperature. A: atresia; GM: gamete maturation, OG: onset of gametogenesis, S: spawn.

hatchery resources, such data is crucial to the understanding of bivalve reproduction in both natural and farmed populations.

Despite the high proportion of atretic gametes at the second spawning, both IT and HT oysters partially spawned at this time. However, the spawning effort of the IT oysters was double that of the HT oysters, suggesting that under intermediateturbidity conditions, $C$. gigas contributes more total gametes (normal + atretic) to the ecosystem. The measure of reproductive success is obviously the subsequent densities of larvae and juveniles; determinations of these numbers are currently underway for both sites (Dutertre et al. 2009).

\section{Conclusion}

The data of the present study highlight the influence of both temperature (fine-scale and seasonal variations) and turbidity on reproduction in farmed $C$. gigas. Similar data should also be obtained for feral populations, which presumably also contribute to their own proliferation. Such information will be important for management of the rapidly-expanding feral population of C. gigas in the variously - turbid habitats throughout the world where they have been introduced for culture.
Acknowledgements. The authors wish to thank David Lecossois for the installation of oyster bags in his oyster-farming parks and the Vendée Naissains society for the supply of hatchery-born spats. We thank Odile Aumaille and Joseph Baudet for their technical assistance in histological analyses. Three anonymous referees provided very extensive and constructive comments, for which we are very grateful. This work was funded by the Syndicat Mixte pour le Développement de l'Aquaculture et de la Pêche de la région des Pays de la Loire and M. Dutertre was supported by a $\mathrm{PhD}$ scholarship from the Ministère Français de la Recherche et de l'Enseignement Supérieur.

\section{References}

Anderson T.J., Pejrup M., 2001, Suspended sediment transport on a temperate, microtidal mudflat, the Danish Wadden Sea. Mar. Geol. 173, 69-85.

Andrews J.D., 1979, Pelecypoda:Ostreidae. In: Giese A.C., Pearse J.S. (Eds.), Reproduction of Marine Invertebrates. Molluscs: Pelecypods and lesser classes. Academic Press, New York, pp. 293-341.

Arakawa K.Y., 1990, Natural spat collecting in the Pacific oyster Crassostrea gigas (Thunberg). Mar. Behav. Physiol. 17, 95-128.

Barber B.J., Getchell R., Shumway S., Schick D., 1988, Reduced fecundity in a deep-water population of the giant scallop Placopecten magellanicus in the gulf of Maine, USA. Mar. Ecol. Prog. Ser. 42, 207-212.

Barillé L., Haure J., Cognie B., Leroy A., 2000, Variations in pallial organ and eulatero-frontal cirri in response to high particulate matter concentrations in the oyster Crassostrea gigas. Can. J. Fish. Aquat. Sci. 57, 837-843.

Barillé L., Prou J., Héral M., Razet D., 1997, Effects of high natural seston concentration on the feeding, selection and absorption of the oyster Crassostrea gigas. J. Exp. Mar. Biol. Ecol. 212, 149172.

Barillé-Boyer A.-L., Barillé L., Massé H., Razet D., Héral M., 2003, Correction for particulate organic matter as estimated by loss on ignition in estuarine ecosystems. Estuar. Coast. Shelf Sci. 58, 147-153.

Beninger P.G., 1987, A qualitative and quantitative study of the reproductive cycle of the giant scallop, Placopecten magellanicus, in the Bay of Fundy (New Brunswick, Canada). Can. J. Zool. 65, 495-498.

Beninger P.G., Cannuel R., Blin J.-L., Pien S., Richard O., 2001, Reproductive characteristics of the archaeogastropod Megathura crenulata. J. Shellfish Res. 20, 301-307.

Beninger P.G., Lucas A., 1984, Seasonal variations in condition, reproductive activity, and gross biochemical composition of two species of adult clam reared in a common habitat: Tapes decussatus L. (Jeffreys) and Tapes philippinarum (Adams and Reeve). J. Exp. Mar. Biol. Ecol. 79, 19-37.

Beninger P.G., Valdizan A., Decottignies P., Cognie B., 2008, Impact of seston characteristics on qualitative particle selection sites and efficiencies in the pseudolamellibranch bivalve Crassostrea gigas. J. Exp. Mar. Biol. Ecol. 360, 9-14.

Berg J.A., Newell R.I.E., 1986, Temporal and spatial variations of seston available to the suspension feeder Crassostrea virginica. Estuar. Coast. Shelf Sci. 23, 375-386.

Bourlès Y., Alunno-Bruscia M., Pouvreau S., Tollu G., Leguay D., Arnaud C., Goulletquer P., Kooijman S.A.L.M., 2009, Modelling growth and reproduction of the Pacific oyster Crassostrea gigas: Advances in the oyster-DEB model through application to a coastal pond. J. Sea Res. 62, in press. 
Brandt G., Wehrmann A., Wirtz K.W., 2008, Rapid invasion of Crassostrea gigas into the German Wadden Sea dominated by larval supply. J. Sea Res. 59, 279-296.

Cardoso J.F.M.F., Langlet D., Loff J.F., Martins A.R., Witte J.I.J., Santos P.T., van der Veer H.W., 2007, Spatial variability in growth and reproduction of the Pacific oyster Crassostrea gigas (Thunberg, 1793) along the west European coast. J. Sea Res. 57, 303-315.

Chávez-Villalba J., Barret J., Mingant C., Cochard J.C., Le Pennec M., 2002, Autumn conditioning of the oyster Crassostrea gigas: A new approach. Aquaculture 210, 171-186.

Chávez-Villalba J., Cochard J.C., Le Pennec M., Barret J., EnríquezDíaz M., Cáceres-Martínez C., 2003, Effects of temperature and feeding regimes on gametogenesis and larval production in the oyster Crassostrea gigas. J. Shellfish Res. 22, 721-731.

Chávez-Villalba J., Mingant C., Cochard J.C., Le Pennec M., 2001, Gamétogenèse chez l'huître Crassostrea gigas de l'Aber Benoît (Bretagne, France), à la limite nord de son aire de reproduction. Haliotis 30, 1-12.

Cognie B., Haure J., Barillé L., 2006, Spatial distribution in a temperate coastal ecosystem of the wild stock of the farmed oyster Crassostrea gigas (Thunberg). Aquaculture 259, 249-259.

Conover W.J. 1999, Practical nonparametric statistics. $3^{\text {rd }}$ edition, John Wiley \& Sons, Inc., New York.

DeVlaming V., Grossman G., Chapman F., 1982, On the use of the gonadosomatic index. Comp. Biochem. Physiol. A 73A, 31-39.

Diederich S., 2006, High survival and growth rates of introduced Pacific oysters may cause restrictions on habitat use by native mussels in the Wadden Sea. J. Exp. Mar. Biol. Ecol. 328, 211227.

Diederich S., Nehls G., van Beusekom J.E.E., Reise K., 2005, Introduced Pacific oysters (Crassostrea gigas) in the northern Wadden Sea: invasion accelerated by warm summers? Helgol. Mar. Res. 59, 97-106.

Dorange G., Le Pennec M., 1989, Ultrastructural study of oogenesis and oocytic degeneration in Pecten maximus from the Bay of $\mathrm{St}$ Brieuc. Mar. Biol. 103, 339-348.

Drinkwaard A.C., 1999, Introductions and developments of oysters in the North Sea area: a review. Helgol. Meeresunters 52, 301-308.

Dupont C., Gruet Y., 2005, Malacofaune et crustacés marins des amas coquilliers mésolithiques de Beg-an-Dorchenn (Plomeur, Finistère) et de Beg-er-Vil (Quiberon, Morbihan). In : Marchand G., Tresset A., Unité et diversité des processus de néolithisation sur la façade atlantique de l'Europe $\left(6^{\mathrm{e}}-4^{\mathrm{e}}\right.$ millénaires avant J.C.). Mém. Soc. Préhist. Française 36, 139-161.

Dutertre M., Beninger P.G., Barillé L., Papin M., Haure J., 2009, Rising water temperatures, reproduction and recruitment of an invasive oyster, Crassostrea gigas, on the French Atlantic coast. Mar. Environ. Res. 68.

Enríquez-Díaz M., Pouvreau S., Chávez-Villalba J., Le Pennec M., 2009, Gametogenesis, reproductive investment, and spawning behavior of the Pacific giant oyster Crassostrea gigas: evidence of an environment-dependant strategy. Aquacult. Int. 17.

Fabioux C., Huvet A., Le Souchu P., Le Pennec M., Pouvreau S., 2005, Temperature and photoperiod drive Crassostrea gigas reproductive internal clock. Aquaculture 250, 458-470.

Fegley S.R., MacDonald B.A., Jacobsen T.R., 1992, Short-term variation in the quantity and quality of seston available to benthic suspension feeders. Estuar. Coast. Shelf Sci. 34, 393-412.

Flassch J.P., Leborgne Y., 1992, Introduction in Europe, from 1972 to 1980, of the Japanese Manila clam (Tapes philippinarum) and effects on aquaculture production and natural settlement. ICES J. Mar. Sci. 194, 92-96.
Gosling E., 2003 (Ed.), Bivalve molluscs: biology, ecology and culture. Fishing News Books, Blackwell Science, Oxford.

Grizel H., Héral M., 1991, Introduction into France of the Japanese oyster (Crassostrea gigas). J. Cons. Int. Explor. Mer, 47, 399 403.

Kobayashi M., Hofmann E.E., Powell E.N., Klinck J.M., Kusaka K., 1997, A population dynamics model for the Japanese oyster, Crassostrea gigas. Aquaculture 149, 285-321.

Kochmann J., Bushbaum C., Volkenborn N., Reise K., 2008, Shift from native mussels to alien oysters: Differential effects of ecosystem engineers. J. Exp. Mar. Biol. Ecol. 364, 1-10.

Lango-Reynoso F., Chávez-Villalba J., Cochard J.C., Le Pennec M., 2000, Oocyte size, a means to evaluate the gametogenic development of the Pacific oyster, Crassostrea gigas (Thunberg). Aquaculture 190, 183-199.

Le Pennec M., Beninger P.G., Dorange G., Paulet Y.M., 1991, Trophic sources and pathways to the developing gametes of Pecten maximus (Bivalvia: Pectinidae). J. Mar. Biol. Assoc. UK 71, 451-463.

Lorenzen C.J., 1967, Determination of chlorophyll and pheopigments: spectrophotometric equations. Limnol. Oceanogr. 12, 343-346.

Lubet P., Besnard J.Y., Faveris R., 1987, Compétition énergétique entre tissu musculaire et gonadique chez la coquille St-Jacques (Pecten maximus L.). Haliotis 16, 173-180.

Lucas A., 1982, La nutrition des larves de bivalves. Océanis 8, $363-$ 388.

Mann R., 1979, Some biochemical and physiological aspects of growth and gametogenesis in Crassostrea gigas and Ostrea edulis grown at sustained elevated temperatures. J. Mar. Biol. Assoc. UK 59, 95-110.

Martoja R., Martoja-Pierson M., 1967, Initiation aux techniques de l'histologie animale. Masson \& Cie (Eds.), Paris.

Morales-Alamo R., Mann R., 1989, Anatomical features in histological sections of Crassostrea virginica (Gmelin, 1791) as an aid in measurements of gonad area for reproductive assessment. J. Shellfish Res. 8, 71-82.

Morvan C., Ansell A.D., 1988, Stereological methods applied to reproductive cycle of Tapes rhomboides. Mar. Biol. 97, 355-364.

Paulet Y.M., Lucas A., Gerard A., 1988, Reproduction and larval development in two Pecten maximus (L.) populations from Brittany. J. Exp. Mar. Biol. Ecol. 119, 145-156.

Pazos A.J., Román G., Acosta C.P., Abad M., Sánchez J.L., 1996, Stereological studies on the gametogenic cycle of the scallop, Pecten maximus, in suspended culture in Ria de Arousa (Galicia, NW Spain). Aquaculture 142, 119-135.

Pejrup M., 1986, Parameters affecting fine-grained suspended sediment concentrations in a shallow micro-tidal estuary, Ho Bugt. Estuar. Coast. Shelf Sci. 22, 241-254.

Pipe R.K., 1987, Oogenesis in the marine mussel Mytilus edulis: an ultrastructural study. Mar. Biol. 95, 405-414.

Reise K., Gollasch S., Wolff W., 1999, Introduced marine species of the North Sea coasts. Helgol. Mar. Res. 52, 219-234.

Rico-Villa B., Pouvreau S., Robert R., 2009, Influence of food density and temperature on ingestion, growth and settlement of Pacific oyster larvae, Crassostrea gigas. Aquaculture 287, 395-401.

Robinson W.E., Wehling W.E., Morse M.P., McLeod G.C., 1981, Seasonal changes in soft-body component indices and energy reserves in the Atlantic deep-sea scallop, Placopecten magellanicus. Fish. Bull. 79, 449-458.

Ruesink J.L., Lenihan H.S., Trimble A.C., Heiman K.W., Micheli F., Byers J.E., Kay M.C., 2005, Introduction of non-native oysters: ecosystem effects and restoration implications. Annu. Rev. Ecol. Evol. Syst. 36, 643-689. 
Ruiz C., Abad M., Sedano F., Garcia-Martin L.O., Sánchez-López J.L., 1992, Influence of seasonal environmental changes on the gamete production and biochemical composition of Crassostrea gigas (Thunberg) in suspended culture in El Grove, Galicia, Spain. J. Exp. Mar. Biol. Ecol. 155, 249-262.

Sastry A.N., 1979, Pelecypoda (excluding Ostreidae). In: Giese A.C., Pearse J.S. (Eds.), Reproduction of Marine Invertebrates. Molluscs: Pelecypods and lesser classes. Academic Press, New York, pp. 113-292.

Seno H., Hori J., Kusakabe D., 1926, Effects of temperature and salinity on the development of the eggs of the common Japanese oyster, Ostrea gigas Thunberg. J. Imp. Fish. Inst. 22, 41-47.

Shatkin G., Shumway S.E., Hawes R., 1997, Considerations regarding the possible introduction of the Pacific oyster (Crassostrea gigas) to the Gulf of Maine: a review of global experience. J. Shellfish Res. 16, 463-477.

Shpigel M., 1989, Gametogenesis of the european flat oyster (Ostrea edulis) and pacific oyster (Crassostrea gigas) in farm water in Israel. Aquaculture 80, 343-349.

Smaal A., van Stralen M., Craeymeersch J., 2005, Does the introduction of the Pacific oyster Crassostrea gigas lead to species shifts in the wadden sea? In: Dame R.F., Olenin S. (Eds.) The Comparative Roles of Suspension-Feeders in Ecosystems. Dordrecht, Kluwer (NATO Science Series IV). Earth Environ. Sci. 47, 277-289.
Steele S., Mulcahy M.F., 1999, Gametogenesis of the oyster Crassostrea gigas in southern Ireland. J. Mar. Biol. Assoc. UK 79, 673-686.

Thompson R.J., 1977, Blood chemistry, biochemical composition, and the annual reproductive cycle in the giant scallop, Placopecten magellanicus, from southeast Newfoundland. J. Fish. Res. Board Can. 34, 2104-2116.

Thresher R., Grewe P., Patil J.G., Whyard S., Templeton C.M., Chaimongol A., Hardy C.M., Hinds L.A., Dunham R., 2009, Development of repressible sterility to prevent the establishment of feral populations of exotic and genetically modified animals. Aquaculture 290, 104-109.

Troost K., Gelderman E., Kamermans P., Smaal A.C., Wolff W.J., 2009, Effects of an increasing filter feeder stock on larval abundance in the Oosterschelde estuary (SW Netherlands). J. Sea Res. 61, 153-164.

van der Meer J., 2006, An introduction to Dynamic Energy Budget (DEB) models with special emphasis on parameter estimation. J. Sea Res. 56, 85-102.

Ventilla R.F., 1984, Recent developments in the Japanese oyster culture industry. Adv. Mar. Biol. 21, 1-57.

Wehrmann A., Herlyn M., Bungenstock F., Hertweck G., Millat G., 2000, The distribution gap is closed-first record of naturally settled Pacific oysters (Crassostrea gigas) in the East Frisian Wadden Sea, North Sea. Senckenb. Marit. 30, 153-160. 